\title{
Implementasi Komunikasi Orang Tua dan Anak dalam Bidang Pendidikan
}

\author{
Delly Mustafa \\ ABSTRACT \\ In the education world, from primary level to the university, parents role are very dominant in \\ determining their children achievement. The children achivement in family were depended on \\ the harmony of communication between parents (father and mother) related with children \\ academic achievement. There were some guidelines to raise children in family livelihood. \\ Parents must know the style of parenting in order to properly choose \\ the right way for raising their children.
}

Kata kunci: komunikasi antarpribadi, pendidikan

\section{Pendahuluan}

Anak, keluarga, dan masa depan bangsa merupakan tiga hal yang saling berkaitan. Di antara tiga hal itu, keluarga mempunyai kedudukan kunci dan sentral. Perkembangan dimulai dan dimungkinkan dalam keluarga. Oleh karenanya, pengaruh keluarga amat besar pada proses perkembangan, pengembangan potensi, dan pembentukan pribadi anak. Komunikasi orang tua dengan anak, pergaulan antara orang tua dan anak, sikap pergaulan orang tua terhadap anaknya, serta rasa dan penerimaan tanggung jawab orang tua terhadap anaknya akan membawa dampak pada kehidupan anak di masa kini, dan juga di hari tua. Demikian pula dengan anak ketika memasuki sekolah. Peranan dan partisipasi orang tua masih tetap dibutuhkan lewat bimbingan belajar kepada anak, pengawasan di luar jam sekolah, ataupun dalam bentuk kerjasama dengan sekolah.

Orang tua mempunyai peranan pertama dan utama bagi anak-anaknya selama sang anak belum dewasa dan mampu berdiri sendiri. Untuk membawa anak kepada kedewasaan, orang tua harus memberi teladan yang baik karena anak suka mengimitasi orang yang lebih tua atau orang tuanya. Setiap orang tua akan senantiasa berusaha untuk merencanakan dan membangun kehidupan layak bagi anak-anak mereka. Memenuhi kebutuhan keseharian anak, dari kebutuhan primer sampai kebutuhan sekunder, termasuk kebutuhan akan pendidikan.

Pendidikan adalah suatu proses budaya untuk meningkatkan harkat dan martabat manusia, baik pendidikan informal maupun formal. Pendidikan informal berlangsung dalam lingkungan keluarga, dimulai sejak anak sanggup melakukan komunikasi, khususnya dengan orang tua, berupa penanaman nilai-nilai, norma-norma, etika sebagai penuntun dalam berperilaku, serta belajar untuk bertanggung jawab.

Dalam hal ini, orang tua harus dapat menciptakan iklim kondusif untuk pertumbuhan dan perkembangan anak secara maksimal dan efisien. Orang tua, sebagai pendidik (primer), harus meletakkan dasar-dasar pendidikan dalam semua aspeknya. Sedangkan pendidikan formal berlangsung di sekolah dan dilaksanakan oleh para guru dan dosen. 
Persoalan pendidikan adalah persoalan manusia. Pendidikan adalah khusus untuk manusia. Manusia, dalam proses perkembangan hidupnya, melalui fase yang bertingkat-tingkat. Tiap-tiap fase memperlihatkan tingkah laku yang berbeda-beda. Manusia dalam menuju kedewasaan menempuh proses yang sangat panjang, dan di dalamnya mengalami pengaruh-pengaruh yang beraneka ragam, baik dari dalam dirinya sendiri maupun dari lingkungan hidupnya.

Selain faktor diri anak sendiri, utamanya faktor bawaan, faktor lingkungan mempunyai porsi besar dalam perkembangan dan keberhasilan anak. Faktor lingkungan yang dimaksud diantaranya orang tua sebagai lingkungan terdekat, guru di sekolah, dan lingkungan sosial lainnya seperti pergaulan di sekolah dan dalam masyarakat. Ketiga lingkungan itu tidak hanya berpengaruh positif bagi anak dalam menempuh pendidikan akan tetapi dapat pula berpengaruh negatif. Berpengaruh positif, dalam pengertian, bahwa orang tua, guru, lingkungan sosial lainnya mampu menciptakan suasana yang mendukung, memancing minat, menggali bakatnya, dan meningkatkan kemampuannya.

Keluarga merupakan pusat pendidikan yang pertama dan terpenting dalam meletakkan dasar dan bentuk pada anak. Karena itu, orang tua dapat memperbesar dan memperkecil pengaruh arah dari lingkungan pergaulannya terhadap anak, baik direncanakan maupun tidak. Keinginan anak bersekolah sangat ditentukan oleh kondisi orang tua, serta dukungan berupa penyediaan fasilitas sekolah yang sangat menentukan kemampuan dan usaha anak untuk belajar.

Dukungan lain dari orang tua yang dapat membimbing anak untuk belajar adalah:

(1) Menyediakan fasilitas belajar.Yang dimaksud di sini ialah alat tulis, buku, buku pelajaran, dan tempat untuk belajar, sehingga dapat mendorong anak untuk lebih giat belajar, sehingga anak dapat meningkatkan prestasi belajarnya.

(2) Mengawasi kegiatan belajar anak di rumah. Orang tua perlu mengawasi kegiatan belajar anak di rumah karena dengan mengawasi kegiatan belajar anaknya, orangtua dapat mengetahui apakah anaknya belajar dengan sebaik-baiknya.

(3) Mengawasi penggunaan waktu belajar anak di rumah.Orang tua perlu mengawasi penggunaan waktu karena dengan mengawasi orang tua dapat mengetahui apakah anaknya mengggunakan waktu belajar dengan teratur dan dengan sebaik-baiknya.

(4) Mengenal kesulitan-kesulitan anak dalam belajar. Orang tua perlu mengenali kesulitankesulitan anak dalam belajar dengan bertanya kepada anak ihwal pelajaran-pelajaran yang sukar diikuti, atau bertanya kepada guru mengenai pelajaran-pelajaran yang sukar diikuti anak.

(5) Menolong anak mengatasi kesulitan belajar. Untuk mengatasi kesulitan belajar, orang tua dapat memberikan keterangan yang diperlukan anak, atau minta bantuan pada orang lain yang lebih mampu.

Dengan berbagai dukungan dari orang tua, akan terjalin keakraban di antara orang tua dan anak sehingga dapat membantu anak dalam kegiatan belajar anak guna meningkatkan prestasi belajarnya.

\section{Komunikasi Orangtua dan Anak dalam Bidang Pendidikan}

\subsection{Pentingnya Komunikasi dalam Keluarga}

Komunikasi ada di mana-mana: di rumah, di kampus, di kantor, di mesjid, bahkan bioskop. Komunikasi menyentuh segala aspek kehidupan kita. Sebuah penelitian mengungkapkan bahwa $70 \%$ waktu kita, selama terjaga, digunakan untuk berkomunikasi. Komunikasi juga menentukan kualitas hidup kita. Dengan berkomunikasi, kita membentuk saling pengertian guna menumbuhkan persahabatan, memelihara kasih sayang, menyebarkan pengetahuan, dan melestarikan peradaban. Di sisi lain, dengan komunikasi pula, kita menyuburkan perpecahan, menghidupkan permusuhan, menanamkan kebencian, merintangi kemajuan, dan menghambat pemikiran. 
Kualitas hidup kita, hubungan kita dengan sesama manusia dapat ditingkatkan dengan memahami dan memperbaiki komunikasi yang kita lakukan. Dalam kehidupan sehari-hari, kita menemukan peristiwa komunikasi terjadi di manamana. Istilah komunikasi sendiri berpangkal pada kata bahasa Latin communis, yang artinya membuat kebersamaan atau membangun kebersamaan di antara dua orang atau lebih. Komunikasi juga berasal dari akar kata bahasa Latin communico, yang artinya membagi (Cherry dalam Stuart, 1983).

Jadi, komunikasi berlangsung bila di antara mereka yang terlibat terdapat kesamaan makna mengenai hal yang dikomunikasikan. Di sini, pengertiandiperlukan agar komunikasi dapat berlangsung, sehingga hubungan mereka (komunikasi dalam keluarga) itu bersifat komunikatif. Sebaliknya, jika tidak ada pengertian, komunikasi tidak akan berlangsung, dan hubungan antara orang-orang pun dikatakan tidak komunikatif.

Rogers dan Kincaid (1981) mengemukakan definisi komunikasi sebagai

“... suatu proses di mana dua orang atau lebih membentuk atau melakukan pertukaran informasi satu dengan yang lainnya, hingga pada gilirannya akan tiba pada saling pengertian yang mendalam."

Rogers mencoba menspesifikasi hakikat suatu hubungan dengan pertukaran informasi (pesan). Yang dikehendakinya adalah perubahan sosial dan tingkah laku, serta kebersamaan, dalam menciptakan saling pengertian dari orang-orang yang ikut serta dalam suatu proses komunikasi.

Dari definisi komunikasi yang telah dikemukakan, maka jelas bahwa komunikasi antarmanusia hanya bisa terjadi jika ada seseorang yang menyampaikan pesan kepada orang lain dengan tujuan tertentu. Ini berarti, komunikasi hanya bisa terjadi kalau didukung oleh adanya sumber, pesan, media, penerima, dan efek. Unsurunsur ini disebut komponen atau elemen komunikasi.

Komponen-komponen komunikasi tersebut adalah:

(1) Sumber

Semua peristiwa komunikasi akan melibatkan sumber sebagai pembuat atau pengirim informasi. Dalam komunikasi antarmanusia, sumber bisa terdiri dari satu orang, tetapi bisa juga dalam bentuk kelompok. Sumber sering disebut pengirim, komunikator atau source, sender, atau encoder.

(2) Pesan

Pesan yang dimaksud dalam proses komunikasi adalah sesuatu yang disampaikan pengirim kepada penerima. Pesan dapat disampaikan secara tatap muka atau melalui media komunikasi. Isinya bisa berupa ilmu pengetahuan, hiburan, informasi, nasihat atau propaganda.

(3) Media

Media yang dimaksud di sini ialah alat yang digunakan untuk memindahkan pesan dari sumber kepada penerima. Terdapat beberapa pendapat mengenai saluran atau media. Dalam komunikasi antarpribadi, pancaindra dianggap sebagai media komunikasi.

(4) Penerima

Penerima adalah pihak yang menjadi sasaran pesan yang dikirim oleh sumber. Penerima bisa terdiri dari satu orang atau lebih, bisa dalam bentuk kelompok, partai atau negara.

(5) Pengaruh

Pengaruh atau efek adalah perbedaan antara apa yang dipikirkan, dirasakan, dan dilakukan oleh penerima sebelum dan sesudah menerima pesan. Pengaruh ini bisa terjadi pada pengetahuan, sikap, dan tingkah laku seseorang.

Yang penting dalam komunikasi adalah bagaimana caranya agar suatu pesan yang disampaikan komunikator menimbulkan dampak atau efek tertentu pada sasaran komunikasi (komunikan). Dampak yang ditimbulkan dapat diklasifikasikan menurut kadarnya, yakni:

(1) Dampak kognitif, yaitu dampak pada komunikan yang menyebabkannya menjadi tahu atau meningkat intelektualnya.

(2) Dampak afektif. Di sini, tujuan komunikator bukan hanya sekedar supaya komunikan tahu, tetapi juga tergerak hatinya, dan menimbulkan perasaan tertentu misalnya perasaan iba, 
terharu, sedih, dan sebagainya.

(3) Dampak behavioral, yakni dampak pada komunikan dalam bentuk perilaku, tindakan, atau kegiatan.

\subsection{Pentingnya Komunikasi Antarpribadi}

Komunikasi merupakan dasar seluruh interaksi antarmanusia. Karena, tanpa komunikasi, interaksi antarmanusia, baik secara perorangan, kelompok, maupun organisasi tidak mungkin terjadi. Sebagian besar interaksi di antara manusia berlangsung dalam situasi komunikasi antarpribadi.

Berdasarkan kenyataan tersebut, jenis komunikasi antarpribadi dipandang sangat efektif dalam hubungan antarpribadi, karena memiliki keistimewaan berupa efek dan umpan balik, aksi dan reaksi verbal dan nonverbal yang langsung terlihat di antara komunikator dengan komunikan. Selain itu, jarak fisik partipasi yang dekat dan dilakukan dengan saling pengertian dapat mengembangkan komunikasi antarpribadi yang memuaskan kedua belah pihak.

Komunikasi antarpribadi menurut Devito dalam Liliweri (1997:12) adalah “ ... pengiriman pesan-pesan dari seseorang dan di terima oleh orang lain atau sekelompok orang dengan efek dan umpan balik yang langsung." Komunikasi antarpribadi dalam definisi ini merupakan proses pengiriman dan penerimaan pesan antara dua orang atau di antara sekelompok kecil orang, dengan berbagai efek dan umpan balik (feedback).

Komunikasi antarpribadi dapat dipergunakan untuk berbagai tujuan. Ada enam tujuan komunikasi antarpribadi yaitu:

(1) Mengenal diri sendiri dan orang lain. Komunikasi antarpribadi memberikan kesempatan bagi kita untuk memperbincangkan diri kita sendiri. Dengan membicarakan diri kita pada orang lain, kita akan mendapat perspektif baru tentang diri kita dan memahami lebih mendalam sikap dan perilaku kita.

(2) Mengetahui dunia luar. Komunikasi antarpribadi juga memungkinkan kita memahami lingkungan kita dengan baik terkait dengan obyek, kejadian-kejadian, dan orang lain.

(3) Menciptakan dan memelihara hubungan menjadi bermakna. Manusia diciptakan sebagai makhluk individu sekaligus makhluk sosial. Sehingga, dalam kehidupan seharihari, orang ingin menciptakan dan memelihara hubungan dekat dengan orang lain.

(4) Mengubah sikap dan perilaku. Dalam komunikasi antarpribadi, sering kita berupaya menggunakan sikap dan perilaku orang lain. Manakala kita ingin seseorang memilih suatu cara tertentu, kita akan memersuasi orang lain melalui komunikasi antarpribadi.

(5) Bermain dan mencari hiburan. Bermain mencakup semua kegiatan untuk memperoleh kesenangan. Bercerita dengan teman tentang kegiatan di akhir pekan, dan pembicaraanpembicaraan lain yang hampir sama merupakan kegiatan yang bertujuan untuk memperoleh hiburan.

(6) Membantu orang lain. Psikiater, psikolog klinis, dan ahli terapi adalah contoh profesi yang mempunyai fungsi menolong orang lain melalui komunikasi antar pribadi. Demikian pula ketika memberikan nasihat dan saran pada orang lain.

Komunikasi antarpribadi, sebagai suatu bentuk perilaku, dapat berubah dari sangat efektif ke tidak efektif. Suatu ketika, komunikasi bisa lebih buruk. Sementara pada saat lain, bisa menjadi lebih baik. Dalam hal ini, kita bisa melihat karakteristikkarakteristik efektivitas komunikasi antarpribadi.

Karakteristik-karakteristik efektivitas komunikasi antarpribadi oleh Joseph De Vito (1986) dalam bukunya The Interpersonal Communication Book, dirinci sebagai berikut:

(1) Keterbukaan (opennes). Keterbukaan adalah kemampuan untuk saling membuka diri, mengatakan tentang keadaan diri masingmasing pelaku komunikasi. Tidak tertutup dalam menerima pesan dan senantiasa menyampaikan pesan dari dirinya.

(2) Perilaku suportif(supportiveness). Keadaan di mana pelaku komunikasi saling memberi dukungan dan tidak bersikap bertahan (defensif) terhadap pesan yang disampaikan, 
sehingga memperlancar proses komunikasi.

(3) Perilaku positif (positiveness). Sikap positif harus terjadi secara timbal-balik, baik kepada diri sendiri maupun orang lain, utamanya saat proses komunikasi berlangsung. Sikap positif akan memberikan tanggapan ataupun umpan balik juga bersifat positif.

(4) Empati (empathy). Empati adalah kemampuan seseorang untuk menempatkan dirinya pada peranan atau posisi orang lain. Dalam arti, mampu memahami apa yang dirasakan dan dialami orang lain.

(5) Kesamaan (equality). Kesamaan adalah adanya unsur-unsur kesamaan yang terdapat pada pelaku komunikasi. Misalnya, dari segi tujuan yang sama.

Dengan mengetahui karakteristik-karakteristik efektivitas komunikasi antarpribadi, maka komunikasi dapat berjalan dengan baik. Dengan demikian, segala pesan yang disampaikan dapat diterima dengan baik oleh penerima pesan.

\subsection{Keluarga dan Pendidikan Anak}

Keluarga dan pendidikan merupakan dua istilah yang tidak bisa dipisahkan. Sebab, di mana ada keluarga, di situ ada pendidikan. Dimana ada orang tua, di situ ada anak, yang merupakan suatu kemestian dalam keluarga. Keluarga adalah sebuah institusi pendidikan yang utama dan bersifat kodrati. Sebagai komunitas masyarakat kecil, keluarga memiliki arti penting dan strategis dalam pembangunan komunitas masyarakat yang lebih luas. Oleh karena itu, kehidupan keluarga yang harmonis perlu dibangun berdasarkan sistem interaksi yang kondusif, sehingga pendidikan dapat berlangsung dengan baik. Pendidikan dasar yang baik harus diberikan kepada anggota keluarga sedini mungkin dalam upaya memerankan fungsi pendidikan dalam keluarga, yaitu menumbuhkembangkan potensi laten anak, sebagai wahana untuk menstransfer nilai-nilai, dan sebagai agen transformasi kebudayaan.

Ketika keluarga diakui sebagai sebuah komunitas, maka secara realitas objektif diakui pula di dalamnya kebersamaan hidup ayah, ibu, dan anak. Sebagai makhluk sosial, mereka saling berhubungan dan memengaruhi satu dengan lainnya. Dari kegiatan saling berhubungan dan saling memengaruhi, lahirlah pada akhirnya bentukbentuk interaksi sosial dalam keluarga, yang biasanya tidak hanya berlangsung di antara sepasang suami dan istri, antara ayah, ibu, dan anak, antara ayah dan anak, tapi juga antara ibu dan anak, serta di antara anak-anak.

Interaksi sosial yang berlangsung dalam keluarga tidak terjadi dengan sendirinya, tetapi karena adanya tujuan atau kebutuhan bersama antara ibu, ayah, dan anak. Adanya tujuan tertentu yang ingin dicapai atau kebutuhan yang berbeda menyebabkan mereka saling berhubungan dan berinteraksi.

Keluarga merupakan lembaga pertama dalam kehidupan anak, tempat ia belajar dan menyatakan diri sebagai makhluk sosial. Dalam keluarga, anak umumnya berada dalam hubungan interaksi yang intim. Segala sesuatu yang diperbuat anak memengaruhi keluarganya dan sebaliknya. Keluarga memberikan dasar pembentukan tingkah laku, watak, moral, dan pendidikan kepada anak.

Pendidikan adalah suatu proses budaya untuk meningkatkan harkat dan martabat manusia, baik itu pendidikan formal maupun informal. Pendidikan informal dimulai sejak anak sanggup berkomunikasi, khususnya dengan orang tua, berupa penanaman nilai-nilai, norma-norma, etika sebagai penuntun dalam berperilaku, serta belajar untuk bertanggungjawab.

Keluarga dan pendidikan tidak bisa dipisahkan. Selama ini, keluarga telah diakui sebagai salah satu dari Tri Pusat Pendidikan yang menyelenggarakan pendidikan secara kodrati. Menurut Kamrani Buseri (2004:22) “... pendidikan di lingkungan keluarga berlangsung sejak anak lahir. Bahkan, setelah dewasa pun, orang tua masih berhak memberikan nasehatnya kepada anak."

\subsection{Konsep Komunikasi Keluarga dalam Membangun Pendidikan Anak}

Konsep komunikasi dalam suatu keluarga adalah terciptanya efektivitas dan efisiensi komunikasi. Tidak terjalinnya saling pengertian 
dalam keluarga akan menimbulkan disorganisasi keluarga, yaitu kegagalan salah satu anggota keluarga untuk melakukan fungsinya, sehingga terjadi ketidakharmonisan hubungan yang melemahkan ikatan keluarga.

Hubungan orang tua dan anak seharusnya memang berlangsung dengan komunikasi yang efektif. Selain faktor keterbukaan, dukungan, sifat positif, empati, dan kesamaan, beberapa hal yang tidak bisa diluputkan berasal dari diri keduanya, seperti kepribadian, kesadaran diri, konsep diri, selektivitas, dan sebagainya.

Komunikasi antarpribadi seringkali dibangun oleh komunikasi intrapribadi. Komunikasi intrapribadi adalah keadaan ketika seseorang berkomunikasi dengan diri sendiri menyangkut berbagai hal yang berhubungan dengan diri sendiri. Kedua bentuk komunikasi tersebut dapat berlangsung dalam selang waktu bersamaan secara bergantian. Dalam komunikasi orang tua dan anak, misalnya, ketika orang tua mengirim pesan, anak akan berkomunikasi dulu dengan dirinya sebelum memberi umpan balik. Demikian juga sebaliknya. Ketika kedua bentuk komunikasi berjalan dengan baik, maka pengaruhnya pada aktivitas keduanya pun lebih baik. Yang paling terasa adalah pendidikan anak. Orang tua akan dengan mudah mengarahkan anak. Sebaliknya, anak senantiasa puas terhadap dirinya, serta apa yang diperolehnya, terutama dalam peningkatan prestasi belajarnya.

Menurut Natawijaya (1979), "Prestasi belajar adalah hasil yang telah dimiliki dalam hubungannya dengan bahan yang telah dipelajari seperti terlihat dalam tingkah lakunya”. Dari definisi tersebut, tampak bahwa Natawijaya memberi penekanan pada hasil belajar yang terlihat dalam tingkah lakunya. Tinggi rendahnya prestasi belajar seseorang dapat dilihat pada sejauhmana anak dapat menerapkan apa yang telah dipelajarinya dalam bentuk tingkah laku. Sejalan dengan pendapat Abdullah, Ambo Enre (1979:2) mengemukakan bahwa "Prestasi belajar merupakan indikator kualitas pengetahuan yang dikuasai oleh anak didik. Tinggi rendahnya prestasi belajar dapat menjadi indikator sedikit banyaknya pengetahuan yang dikuasai anak didik dalam bidang studi atau kegiatan kurikulum tertentu."

Jadi, prestasi belajar yang dicapai seseorang merupakan hasil interaksi berbagai faktor yang memengaruhi, baik dari dalam maupun dari luar anak. Pada pendidikan anak di sekolah, pengaruh orang tua pun sangat besar. Hubungan prestasi belajar anak ataupun perilaku kehidupan bermasyarakat anak dinyatakan oleh Markum (1999) “....sangat tergantung pada komunikasi yang terjalin di antara mereka, utamanya pihak orang tua, bagaimana orang tua menerapkan pola asuh yang tepat buat anaknya."

Pola asuh sendiri dapat digolongkan menjadi tiga, yakni:

(1) Pola asuh otoriter. Orang tua sangat menentukan disiplin dan menuntut prestasi tinggi pada anaknya. Hanya, sayangnya, orang tua tidak memberi kesempatan kepada anak untuk mengungkapkan pendapat, sekaligus menomorduakan kebutuhan anak.

(2) Pola asuh permisif. Orang tua bersikap demokratis dan penuh kasih sayang. Di sisi lain, kendali orang tua dan tuntutan prestasi anak rendah. Anak di biarkan berbuat sesukanya tanpa beban kewajiban dan target apapun.

(3) Pola asuh otoritatif. Orang tua memegang kendali yang tinggi pada anak, menuntut prestasi yang tinggi, tapi tetap dibarengi sikap demokratis dan kasih sayang yang tinggi pula. Pola asuh ini kuat dalam kontrol, tetapi tetap memberi tempat untuk pendapat anak. Pola asuh otoritatif akan mendorong pembentukan sifat kerja keras, disiplin, komitmen, prestasi, memberi dan realistis pada individu. Sementara sifat yang paling besar kontribusinya bagi tingginya prestasi anak adalah sifat disiplin. Pola asuh otoritatif bisa dilakukan sejak dini, seperti dengan memberi anak target belajar yang telah disepakati. Intinya, terdapat ruang tawar-menawar antara orang tua dan anak, segala aturan yang akan diberlakukan telah disepakati lebih dulu.

Di luar dari pola asuh tadi, Thomas Gordon (1991) menjelaskan cara mendidik dan mengasuh anak sebagai berikut: 
(1) Pola komunikasi anti-kalah. Dalam menyelasaikan konflik dengan baik, usahakan agar tidak ada pihak yang merasa dikalahkan. Cari penyelesaian atau berkomunikasilah sedemikian rupa sehingga pihak-pihak yang salah dapat menyadari kesalahannya.

(2) Mendengar secara aktif. Dengan mendengar secara aktif, setiap anggota keluarga dapat menangkap fakta dan perasaan yang tersirat dalam pesan.

(3) Menyampaikan pesan diri. Bila masing-masing anggota keluarga belajar menyampaikan maksudnya terhadap yang lain, maka masingmasing akan menangkap persoalan yang ada dengan mudah, sehingga saling pengertian dapat tercapai.

Orang tua dan anak harus menyadari hambatan-hambatan dalam berkomunikasi, antara lain sikap memerintah, menyalahkan, mencemooh, mempermalukan, dan sebagainya.

\section{Simpulan}

Tidak semua orangtua mempunyai pengaruh dan peran yang sama terhadap diri seorang anak. Pengaruh ini ditentukan oleh seberapa dekat hubungan orangtua terhadap diri anak. Dengan kata lain, yang paling berpengaruh dalam pembentukan pribadi anak adalah sosok yang terdekat dengan anak itu sendiri. Orang terdekat ini mempunyai ikatan emosional, seperti orang tua, saudara (keluarga), teman, guru, masyarakat ataupun tokoh yang menjadi idola seorang anak.

Porsi terbesar yang berpengaruh pada anak adalah orang tua. Orang tua dan anak adalah satu ikatan dalam jiwa. Dalam keterpisahan raga, jiwa mereka bersatu dalam ikatan keabadian dalam bentuk hubungan emosinal antara anak dan orang tua yang tercermin dalam perilaku. Sejak lahir, anak telah berkomunikasi dengan orang tuanya dalam bentuk komunikasi antarpribadi.

Komunikasi antarpribadi yang dimaksud di sini ialah proses komunikasi yang berlangsung antara dua orang atau lebih secara tatap muka ataupun melalui medium, bersifat langsung dalam bentuk percakapan. Fungsi komunikasi antarpribadi ialah berusaha meningkatkan hubungan insani, menghindari dan mengatasi konflik pribadi, mengurangi ketidakpastian sesuatu, serta berbagi pengetahuan dan pengalaman dengan orang lain. Komunikasi antarpribadi dipandang sebagai bentuk komunikasi paling efektif dalam hubungan orang tua dan anak. yang berfungsi untuk mengubah sikap maupun tingkah laku anak menjadi lebih baik

Pada akhirnya, komunikasi yang terjalin antara orang tua dan anak haruslah berjalan dengan baik dan efektif. Komunikasi antarpribadi dinyatakan efektif bila pertemuan komunikasi merupakan hal yang menyenangkan bagi orang tua maupun anak. Di dalam berkomunikasi, sebaiknya orang tua bersikap menghormati anak, jangan melukai harga diri anak. Hal ini tidaklah berarti bahwa orang tua harus menuruti anak. Orangtua jangan segansegan memberikan pujian dan penghargaan bila anak pantas menerimanya. Penghargaan dan pujian juga pantas diberikan kepada anak yang telah mencapai prestasi dalam pendidikannya yang disebabkan oleh usahanya sendiri.

\section{Daftar Pustaka}

Cangara, Hafied. 2003. Pengantar Ilmu Komunikasi. Jakarta: PT Raja Grafindo Persada.

Djamarah, Syaiful Bahri. 2004. Pola Komunikasi Orang Tua dan Anak. Jakarta: Rineka Cipta.

D.Gunarsa, Singgih. 1995. Psikologi Keluarga. Jakarta: PT. BPK Gunung Mulia.

Effendy, Onong Uchjana. 1993. Ilmu, Teori dan Filsafat Komunikasi. Bandung: PT Citra Aditya Bakti.

Hasbullah. 2001. Dasar-Dasar Ilmu Pendidikan. Jakarta: PT Raja Grafindo Persada.

Kartono, Kartini. 1992. Peranan Keluarga Memandu Anak. Jakarta: Rajawali Pers.

Liliweri, Alo. 1997. Komunikasi Antarpribadi. Bandung: Citra Aditya Bakti. 
Markum, Enoch M. 1991. Anak, Keluarga dan Masyarakat (Tinjauan atas Disiplin, Kebebasan, Etika, dan Proses Belajar). Jakarta: Pustaka Sinar Harapan.

Sobur, Alex. 1991. Komunikasi Orang Tua dan Anak. Bandung: Angkasa.

Supratiknya, A. 1995. Komunikasi Antarpribadi (Tinjauan Psikologis). Jokjakarta: Kanisius.
Suryosubroto, B. 1990. Dasar-Dasar Kependidikan. Jakarta: Rineka Cipta.

Soekanto, Soerjono. 1992. Sosiologi Keluarga. Jakarta: Ghalia Indonesia.

Thonthowi, Ahmad. 1993. Psikologi Pendidikan. Bandung: Angkasa.

Widjaja, H.A.W. 2000. Ilmu Komunikasi Pengantar Studi. Jakarta: Rineka Cipta. 